\title{
Comparative Effect of Potentiated Zinc Oxide and Antibiotic Growth Promoters \\ on Intestinal Morphometry and Nutrient Digestibility in Broiler Chickens
}

\section{Babylyn Alday Moog ( $\sim$ babylyn.moog@yahoo.com )}

UPLB CA: University of the Philippines Los Banos College of Agriculture and Food Science https://orcid.org/0000-0002-8843-4633

\section{Amado Angeles}

UPLB CA: University of the Philippines Los Banos College of Agriculture and Food Science

Florinia Merca

UPLB CAS: University of the Philippines Los Banos College of Arts and Sciences

\section{Percival Sangel}

UPLB CA: University of the Philippines Los Banos College of Agriculture and Food Science

\section{Research Article}

Keywords: zinc bacitracin, maduramicin, villi height, crypt depth, potentiation, zinc oxide

Posted Date: July 30th, 2021

DOI: https://doi.org/10.21203/rs.3.rs-718127/v1

License: (c) (1) This work is licensed under a Creative Commons Attribution 4.0 International License.

Read Full License

Version of Record: A version of this preprint was published at Tropical Animal Health and Production on December 14th, 2021. See the published version at https://doi.org/10.1007/s11250-021-03012-7. 


\title{
Comparative Effect of Potentiated Zinc Oxide and Antibiotic Growth Promoters on Intestinal Morphometry and Nutrient Digestibility in Broiler Chickens
}

\author{
*B.A. Moog $^{\mathrm{a}}$, A.A. Angeles ${ }^{\mathrm{a}, \mathrm{b}}$, F.E. Merca ${ }^{\mathrm{c}}$, P.P Sangel ${ }^{\mathrm{a}}$ \\ anstitute of Animal Science, University of the Philippines Los Baños \\ bDairy Training and Research Institute, University of the Philippines Los Baños \\ 'Institute of Chemistry, College of Arts and Sciences, University of the Philippines Los Baños \\ *Corresponding author: bamoog@up.edu.ph, babylyn.moog@yahoo.com
}

Abstract

This study aims to determine the comparative effects of potentiated zinc oxide (pZnO) and antibiotic growth promoters (AGP) supplementation on intestinal morphometry and nutrient digestibility in broiler chickens. Four hundred straight-run day-old broiler chicks were randomly allotted to one of four dietary treatments replicated 10 times with 10 birds per replicate. Dietary treatments were: T1: Basal diets without AGP (negative control; NC), T2: Basal diets with $500 \mathrm{~g} /$ ton Maduramicin $10 \mathrm{~g}$ and $500 \mathrm{~g} /$ ton Zinc bacitracin 150 (positive control; PC), T3: NC added with 150g/ton pZnO, and T4: PC added with 150g/ton pZnO in a $2 \times 2$ factorial design in RCBD. At days 18 and 35, 10 birds were randomly selected per treatment for morphometry of the duodenum, jejunum and ileum. At day 38, eight birds per treatment were used for the nutrient digestibility study. Results showed significant interaction effects $(P<0.05)$ of AGP and pZnO supplementation on day 35 intestinal morphometry of duodenum's villi height and villi height: crypt depth, and ileum's crypt depth; apparent $\mathrm{COD}_{\mathrm{GE}}$, AME, CP, DM and EE. Significant differences $(P<0.05)$ with $\mathrm{pZnO}$ supplementation were only observed on feed intake and FCR of birds fed with $\mathrm{pZnO}$ at days 8-14 and fecal quality at days $0-7$. Results of the study suggest that $\mathrm{pZnO}$ has the potential to replace AGPs without negatively affecting the intestinal morphometry, digestibility and growth performance of broiler chickens.

Keywords: zinc bacitracin, maduramicin, villi height, crypt depth, potentiation, zinc oxide

\section{INTRODUCTION}

Antibiotics have been widely used in animal production not only for treatment but also as part of the approaches being used to enhance performance. They have been supplemented at subtherapeutic doses to improve growth performance and feed conversion efficiency of the animals, hence, the term antibiotic growth promoters (AGPs). Through years, AGPs have been used by the poultry industry as an effective way to enhance animal health status and production efficiency that removing it on poultry operation programs has already been a challenge. However, concerns over development of antibiotic microbial 
resistance are rising leading to search for alternatives. Probiotics, prebiotics and organic acids are some of the well-known alternatives to AGPs together with zinc oxide ( $\mathrm{ZnO})$ in swine.

Zinc oxide can be used in animal diets as a nutritional source of zinc or as a possible alternative to AGPs if used as a pharmacological dose. $\mathrm{ZnO}$ supplementation in swine has been popular in addressing concerns associated with post-weaning diarrhea. Pharmacological dose of $\mathrm{ZnO}$ at $1500-2500 \mathrm{ppm} \mathrm{Zn}$ demonstrated antimicrobial properties and performance improvement in piglets (Hill et al., 2001). In a study by Li et al. (2001), he cited that $\mathrm{ZnO}$ supplementation has led to decrease antibiotic use in feeds, enhance intestinal epithelial morphology and performance, which affect absorption and digestion of nutrients. In swine, $\mathrm{ZnO}$ supplementation in starter diets improves growth and feed conversion ratio (FCR) of newly weaned pigs. However, disadvantages have been found with long-term use of $\mathrm{ZnO}$ at pharmacological dose such as depressed feed intake and efficiency of gain, occurrence of resistance to $\mathrm{Zn}$ in the pig gut bacteria, excessive fecal $\mathrm{Zn}$ excretion and accumulation of $\mathrm{Zn}$ in soils causing serious environmental concerns (Buff et al., 2005; Cavaco et al., 2011; Romeo, 2014; and Weng et al., 2018).

Potentiated zinc oxide $(\mathrm{pZnO})$ is a special grade $\mathrm{ZnO}$ source with 10-15 times larger surface area than regular zinc oxide sources. Its high porosity strengthens its antibacterial property. Studies on swine have shown that $\mathrm{pZnO}$ at $150-300 \mathrm{ppm}$ is as effective as the pharmacological dose of regular $\mathrm{ZnO}$ (Morales et al., 2012; Kromm and Romeo, 2014; and Raquipo et al., 2017).

The role of $\mathrm{pZnO}$ as a possible alternative for AGPs in swine have already been established. However, in poultry, no studies have been conducted yet with the use of $\mathrm{pZnO}$. Therefore, this study aims to determine the comparative effects of $\mathrm{pZnO}$ and AGPs on intestinal morphometry and nutrient digestibility in broiler chickens.

\section{MATERIALS AND METHODS}

A total of 400 day-old, straight-run broiler chicks (Cobb 500) were used in a 35-d growth assay. Broilers were randomly allotted to one of four dietary treatments. Each treatment had 10 replications (cages) with 10 birds per replicate cage. Birds had ad libitum access to feed and water (non-medicated all throughout the study). Broilers were housed at the University Animal Farm, Institute of Animal Science, University of the Philippines Los Baños. The experimental treatments were as follows; T1: Basal diets without AGP (negative control; NC); T2: Basal diets with AGP (positive control; PC; NC $+500 \mathrm{~g} / \mathrm{ton}$ maduramicin ammonium $10 \mathrm{~g}($ Cygro $1 \%)+500 \mathrm{~g} /$ ton zinc bacitracin 150 (Zambac P)); T3: NC added 
with 150g/ton potentiated zinc oxide (HiZox); and T4: PC added with 150g/ton potentiated zinc oxide (HiZox). Zambac P and Cygro $1 \%$ were purchased from a commercial feedmill while HiZox was provided by PhilNutri Corporation.

\section{Intestinal morphometry of broilers}

Two birds from each replicate of each treatment were sacrificed for intestinal morphometry. Three segments $(1 \mathrm{~cm}$ each) were removed from (1) apex of duodenum, (2) midway between the point of entry of the bile ducts and Meckel's diverticulum (jejunum), and (3) $10 \mathrm{~cm}$ proximal to the cecal junction (ileum). Samples were collected at days 18 and 35, fixed in $10 \%$ neutral buffered formalin solution and fixed and stained by Hematoxylin and Eosin in microscopic slides. Measurement of villi height and crypt depth were done using a USB microscope (Dino-Lite ${ }^{\circledR}$.

\section{Nutrient Digestibility}

On day 35 , eight birds from each treatment were randomly selected and transferred to individual metabolism cages. After three days adjustment period, broilers were fed respective dietary treatments containing $0.25 \%$ chromium oxide as an indigestible marker. Collection of feces for three consecutive days began with the appearance of marked feces. Trays were installed under each cage to facilitate total collection of feces. Feathers and other contaminants were removed from the feces prior to oven-drying at $70^{\circ} \mathrm{C}$ until constant weight. The oven-dried feces from each bird for three days were pooled, weighed and ground to pass $0.5 \mathrm{~mm}$ screen and were subjected for proximate analysis and gross energy determination.

\section{Broiler Production Performance and Fecal Scoring}

Daily feed allotments and average body weight were recorded at days $0,7,14,21,28$, and 35 . Data were summarized and average daily gain (ADG), average daily feed intake (ADFI) and feed conversion ratio (FCR) were calculated weekly.

For fecal assessment, assessment of excreta quality in each replicate was performed through visual fecal scoring by three independent scorers; following the fecal quality scores in the study by Garcia et al. (2019). . Figure 1 shows the fecal quality scores that were used in the experiment.

\section{Chemical Analysis}

Samples of treatment diets and feces were submitted to an analytical laboratory (Lipa Quality Control Center, Lipa City, Batangas, Philipines) for proximate, calcium, and phosphorus analyses following the standard procedure of Association of Official Analytical Chemist (AOAC, 2019). GE determination 
96
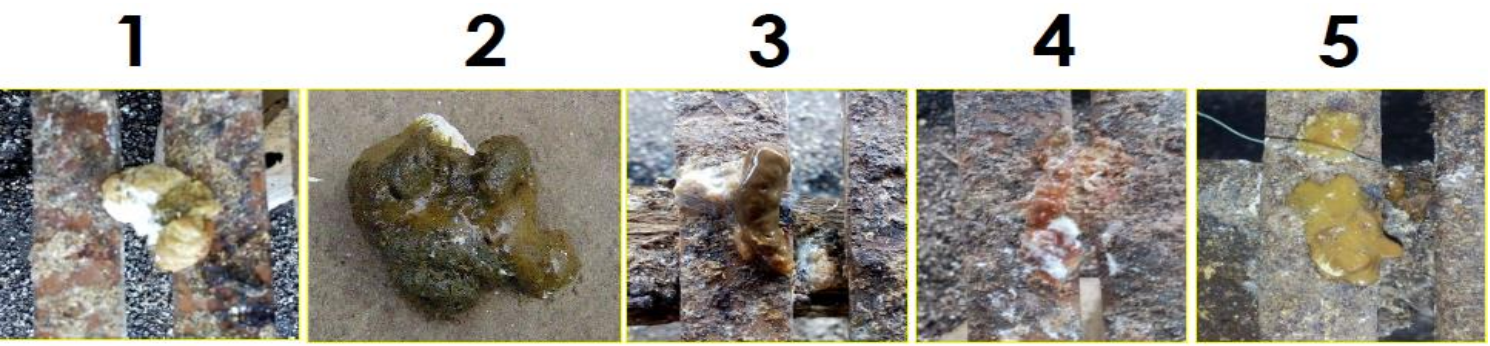

Figure 1. Fecal Quality Scores (1-5): 1 = dry- well-formed excreta with characteristic white uric acid cover; 2- mostly dry excreta with white uric acid cover; 3 - moist excreta with white uric acid cover; 4 wet excreta with less white uric acid cover and droppings lose their shape; and 5 - extremely wet excreta with little to no white uric acid cover.

101

\section{Statistical Analysis:}

Gathered data were checked for outliers, normality (Shapiro-Wilk Test) and equality of variance (F-

104 test) prior to being subjected to analysis of variance (ANOVA) under a 2 × 2 factorial design in RCBD.

105 Comparison of treatment means were done using Tukey's Honest Significance Difference (HSD) Test. The

$106 \alpha$-level that were used to determine significance and tendencies between means were 0.05 and 0.10 ,

107 respectively.

\section{RESULTS}

Table 1 presents the analyzed nutrient composition of the feeds offered to the animals. The

110 analyzed average crude protein contents of negative control diets (22.14, 20.05, and 17.96\%), positive

111 control diets (22.63, 20.46 and $18.59 \%)$, negative control $+\mathrm{pZnO}(22.20,19.88$ and $18.06 \%)$ and positive

112 control $+\mathrm{pZnO}(21.73,20.27$ and $18.07 \%)$ for booster, starter and finisher, respectively, were higher than

113 the calculated amount. For crude fiber, analyzed average crude fiber contents were almost the same to the

114 calculated values for booster to starter diets but lower for finisher diet. Calcium and total phosphorus were

115 almost the same to the calculated nutrient content for booster to finisher diets.

116 Table 1. Analyzed average nutrient composition of broiler diets (as fed basis) ${ }^{1}$

\begin{tabular}{lcccc}
\hline \hline \multirow{2}{*}{ Nutrients } & \multicolumn{4}{c}{ Dietary Treatments } \\
\cline { 2 - 5 } & $\mathbf{N C}$ & $\mathbf{P C}$ & $\mathbf{N C}+\mathbf{p Z n O}$ & $\mathbf{P C}+\mathbf{p Z n O}$ \\
\hline Broiler Booster & & & & \\
Moisture, \% & 11.82 & 11.59 & 12.06 & 11.73 \\
Crude Protein, \% & 22.14 & 22.63 & 22.2 & 21.73 \\
Crude Fiber, \% & 3.05 & 2.87 & 2.97 & 2.95
\end{tabular}


Ether extract, \%

Ash, \%

5.53
8.56

4.86

5.48

5.08

Nitrogen Free Extract, \%

48.90

8.49

7.80

8.32

Calcium, \%

1.04

49.56

49.49

50.19

Total Phosphorus, \%

0.84

0.95

1.07

1.01

Gross Energy, kcal/kg²

3,874

0.75

0.78

0.71

3,848

3,843

3,825

\section{Broiler Starter}

Moisture, $\%$

10.03

9.85

9.92

9.24

Crude Protein, \%

20.05

20.46

19.88

20.27

Crude Fiber, $\%$

3.30

3.08

3.06

3.69

Ether extract, \%

5.32

4.86

4.93

5.61

Ash, \%

7.50

7.83

6.97

8.12

Nitrogen Free Extract, \%

53.80

53.92

55.24

53.07

Calcium, \%

0.88

0.91

0.95

0.98

Total Phosphorus, \%

0.77

0.73

0.76

0.77

Gross Energy, kcal/kg²

3,800

3,789

3,845

3,868

\section{Broiler Finisher}

Moisture, \%

9.79

9.53

9.35

9.48

Crude Protein, \%

17.96

18.59

18.06

18.07

Crude Fiber, \%

2.94

2.57

2.59

2.19

Ether extract, \%

6.95

6.59

6.23

6.93

Ash, \%

6.32

5.86

6.47

6.65

Nitrogen Free Extract, \%

56.04

56.86

57.3

56.68

Calcium, \%

0.78

0.80

0.81

0.81

Total Phosphorus, \%

0.72

0.77

0.75

0.74

Gross Energy, $\mathrm{kcal} / \mathrm{kg}^{2}$

4,022

4,047

4,023

4,031

1 Analyzed at the Lipa Quality Control Center; ${ }^{2}$ Analyzed at the University of the Philippines Los Baños Analytical Lab 2 Dietary treatments were Negative Control (NC); Positive Control (PC; NC + $500 \mathrm{~g} /$ ton Maduramicin ammonium $10 \mathrm{~g}+$ $500 \mathrm{~g} /$ ton Zinc bacitracin 150); $\mathrm{NC}$ added with $150 \mathrm{~g} / \mathrm{ton}$ potentiated $(\mathrm{NC}+\mathrm{pZnO})$; and $\mathrm{PC}$ added with $150 \mathrm{~g} / \mathrm{ton}$ potentiated zinc oxide $(\mathrm{PC}+\mathrm{pZnO})$

\section{Intestinal morphometry}

In the present study, interaction effects of $\mathrm{AGP}$ and $\mathrm{pZnO}$ on intestinal morphometry in broilers

124 has been observed. At day 35, AGP x pZnO interactions were observed for duodenum's villi height (VH) $(P<0.01)$, duodenum's villi height: crypt depth $(\mathrm{VH}: \mathrm{CD})(P=0.01)$ and ileum's $\mathrm{CD}(P=0.04)$. In addition, AGP and pZnO interactions tended to improve the ileum's VH $(P=0.07)$ measurement. Intestinal morphometry results were presented at Table 2 . 


\section{Digestibility of Experimental Broiler Diets}

The apparent nutrient digestibility of dry matter, crude protein, ether extract and energy are presented in Table 3. Results show significant interaction effects of AGPs and pZnO; with dry matter, crude protein, and energy at $P<0.001$ and ether extract at $P=0.01$.

\section{Broiler Production Performance and Fecal Scoring}

Table 4 presents the body weight, body weight gain (BWG), feed intake and feed conversion ratio (FCR) of broilers fed diets with and without AGP and pZnO. Results showed no significant differences on the interaction effects of AGP and pZnO on body weight and body weight gain of broilers.

While for feed intake, significant effect was observed on birds fed with both additives used in the diets on days 8-14 feeding. This effect can be mainly attributed to the contribution of AGP $(P=0.02)$ and $\mathrm{pZnO}(P=0.01)$. Also, data presented shows that birds fed diet without AGP and $\mathrm{pZnO}$ have the highest feed intake while birds fed with both AGP and pZnO have the lowest. The dietary addition of both AGP and $\mathrm{pZnO}$ resulted to lower feed intake in the experiment.

The main effects of $\mathrm{pZnO}$ in the booster diet have been observed to significantly improve the FCR $(P=0.01)$ at days $8-14$ while tended to improve $(P=0.09)$ for broilers at $0-7 \mathrm{~d}$. Best FCR have been observed on birds fed diets with AGP and pZnO while poorest FCR have been observed on diets fed without AGP and $\mathrm{pZnO}$. In addition, the use of AGP tended to improve the FCR of broilers fed with booster diet at days 8-14. However, effect of dietary treatment showed no significant difference on FCR during the starter and finisher stage.

Fecal score was also monitored and the main effects on fecal score of feeding pZnO in the broiler stage at days 0-7 can be seen in Table 5. Results showed significant improvement $(P=0.04)$ in fecal quality with $\mathrm{pZnO}$ supplementation at days 0 -7. In addition, tendency $(P=0.08)$ has been observed with the supplementation of $\mathrm{pZnO}$ at days 22-28.

\section{DISCUSSION}

\section{Intestinal morphometry}

The villi height $(\mathrm{VH})$ and villi height: crypt depth ratio (VH:CD) are used as positive indicators for estimating the integrity of the intestinal mucosal structure, while CD is regarded as negative indicator. In addition, longer $\mathrm{VH}$ and higher $\mathrm{VH}: \mathrm{CD}$ are often correlated to better nutrient absorption while higher $\mathrm{CD}$ is correlated to poorer absorption. The role of zinc in $\mathrm{VH}$ and $\mathrm{VH}: \mathrm{CD}$ in the jejunum have been reported 
160 by Vela et al. (2015). It has been mentioned that zinc deficiency results in the shortening and narrowing of

161 the villi, resulting to reduction of surface area for absorption due to the reduction in mucosal cell

162 proliferation and slower cell migration, as well as increase in the number of apoptotic cells in villi and 163 crypts.

164 As antimicrobial, antibiotics such as carbadox target mainly the gut microbiome in the host from 165 feeding the AGP. It has been reported that gut microbiota can influence intestinal morphology and in swine,

166 decrease in the richness of gut microbial taxa as well as individual species, such as E. coli, have been

167 observed in pigs fed diets containing antibiotics. This has been supported by the decreased crypt

168 depth and increased intestinal VH:CD which was also observed in the mentioned study. (Hung et al., $1692020)$

170 In this study, results of this experiment for ileum's crypt depth at $\mathrm{d} 35$ were in agreement to what 171 was observed by Hung et al (2020), wherein interaction with antibiotics and $\mathrm{ZnO}$ at 150 ppm in piglets

172 were observed. However, as there are limited studies which evaluated the effects of AGPs and $\mathrm{ZnO}$, no

173 further comparison of the results was done for duodenum's VH and VH:CD.

\section{Digestibility of Experimental Broiler Diets}

175 And as there are limited studies showing the effect of AGP and ZnO supplementation in nutrient 176 digestibility, results of the study were not compared to other studies. But this study suggests that there are 177 interaction effects on the action of AGPs and pZnO on broilers' apparent nutrient digestibility on energy, 178 dry matter, crude protein and ether extract.

179 However, looking at the main effects, even though no significant differences were observed, 180 results obtained were in agreement and disagreement to results of studies previously conducted. In a study 181 by Han and Thacker (2010), they observed that pigs fed AGP supplemented diet exhibited significantly $182(P<0.01)$ higher digestibility coefficients for dry matter than pigs fed diets supplemented $\mathrm{ZnO}$; while no 183 significant difference was observed for crude protein and energy.

184 Looking at the effects of $\mathrm{pZnO}$, results in nutrient digestibility were in agreement with what was 185 observed by Garg et al. (2008), Kumar et al. (2002), and Mandal et al. (2007), wherein DM, and CP 186 digestibility were not affected by $\mathrm{ZnO}$ supplementation. However, results were in disagreement with what 187 was observed by Salama et al. (2003) wherein CP and DM digestibility improved with ZnO 188 supplementation. 
In other studies, improvement in nutrient digestibility was observed with the supplementation of

$190 \mathrm{ZnO}$ due to the improved activation of digestive enzymes such as amylase, carboxypeptidases,

191 chymotrypsin, trypsin and lipase in the small intestine and pancreatic tissue (Oh et al., 2021). While for

192 AGPs, Modi et al. (2011) cited that AGPs also increase digestibility of proteins by reducing the proteolytic

193 enzyme secretion by the bacteria.

194 Broiler Production Performance and Fecal Scoring

195 As the birds were randomly allotted at the start of the treatment, significant differences among the

196 weights were not accounted for at the start of the trial. But after a week of feeding until day 14, no significant

197 differences were observed among treatments. In addition, initial body weights of starter and finisher stage

198 also did not differ significantly among treatments.

199 Neither AGP nor pZnO supplementation were observed to affect body weight gain of broilers as

200 there were no significant differences observed on birds fed treatment diets at three feeding stages. Results

201 in this study are in agreement with what was observed by Tomaszewka et al. (2017), Kidd et al. (1992,

202 1994) and Pimentel et al. (1991) wherein no significant differences on body weight and body weight gain

203 of broilers fed with additional zinc oxide. Thus, the results of the experiment suggest that the level of zinc

204 in the diet did not significantly influence broiler growth performance during the 5-week study.

205 For feed intake, results are in agreement to the findings of Jahanian et al. (2008) in broiler chicks,

206 wherein increasing zinc concentration from (by supplementing zinc sulphate to a basal diet containing 25

$207 \mathrm{mg} \mathrm{Zn} / \mathrm{kg}$ ) for 42 days significantly decreased average feed intake. However, results observed are in

208 disagreement to what was observed by Miller et al. (1968) and Swinkels et al. (1994) wherein higher feed

209 intake was observed with diets supplemented with additional zinc.

210 No significant effects with AGP and $\mathrm{pZnO}$ supplementation were observed for FCR. This is in

211 contrast to the results of the study of Ramiah et al. (2019), wherein zinc supplementation exhibited a strong

212 trend in improving the FCR during the overall period ( $p=0.051)$; and Ali et al. (2019) wherein even though

213 no significant differences was observed in FCR in days 1-21, significant difference was then observed in

214 the last 22-42 days.

215 In addition, results indicated significant improvement $(P=0.04)$ in fecal quality with $\mathrm{pZnO}$

216 supplementation at days $0-7$ while tendency $(P=0.08)$ has been observed at days $22-28$. This can be

217 attributed with the role of zinc for the intestinal epithelial barrier maintenance. The junctional complexes 
218 assembled at the lateral membrane of intestinal epithelial cells; tight junctions (TJs), represent a major

219 component of the intestinal barrier (Miyoshi et al.,2015). Tight junctions are crucial for the integrity and

220 the function of the epithelial barrier. In vitro and in vivo studies have shown that reduced tight junction

221 integrity results to "leaky gut" (Awad et al., 2017). In line with this, Wang et al. (2013) cited that zinc has

222 the potential to function as a tight junction modifier and selective enhancer of epithelial barrier function.

223 Zhang and Guo (2009) reported that Zn supplementation increases occludin expression in ileal epithelia

224 while simultaneously increasing barrier function resulting to decrease fecal scores.

225 Results observed showed that performance of birds supplemented with pZnO is comparable to 226 performance of birds supplemented with AGP. Thus, the study suggests that pZnO has the potential to replace AGPs without negatively affecting the intestinal morphometry, digestibility and growth performance of broiler chickens. In addition, $\mathrm{pZnO}$ has the potential to replace AGPs used in poultry diets.

\section{ACKNOWLEDGEMENT}

This research work was supported by PhilNutri Corporation and Animine.

\section{CONFLICT OF INTEREST}

Authors clarify that there is no conflict of interest with any financial, personal, or other relationships with other people or organization related to the material discussed in the manuscript.

238 INFORMED CONSENT. Informed consent was obtained from all individual participants included in the 239 study.

240 AVAILABILITY OF DATA AND MATERIAL. All data generated or analyzed during this study are

241 included in this article.

242 CODE AVAILABILITY. Not Applicable

243 AUTHORS' CONTRIBUTIONS. BM and AA conceived and designed the research, and conducted the

244 experiment. All authors are involved in the analysis of the results of the experiment and write-up of the 245 manuscript. 


\section{REFERENCES}

Ali M, A. Jamal, H. Saeed, M.Z. Abiden, M.H. Nawaz, and A. Irfan.2019. Impact of zinc supplementation on growth performance, carcass traits and immune response in broilers fed antibiotic free diet. Int J Biotechnol Recent Adv. 2019; 2(1): 60-63. doi: 10.18689/ijbr-1000110.

AOAC. 2019. Official methods of analysis. 21st ed. USA: AOAC International.

Awad, W. A., C. Hess, and M. Hess. 2017. Enteric pathogens and their toxin-induced disruption of the intestinal barrier through alteration of tight junctions in chickens. Toxins 9(2):60. doi ARTN 6010.3390/toxins9020060.

Buff C. E., D. W. Bollinger, M.R. Ellersieck, W.A. Brommelsiek, and T.L. Veum. 2005. Comparison of growth performance and zinc absorption, retention, and excretion in weanling pigs fed diets supplemented with zinc-polysaccharide or zinc oxide.J. Anim. Sci.83:2380-2386. doi:10.2527/2005.83102380x.

Cavaco, L.M., H. Hasman, and F.M. Aarestrup. 2011. Zinc resistance of Staphylococcus aureus of animal origin is strongly associated with methicillin resistance. Veterinary Microbiology 150 (3-4), pp.344. 10.1016/j.vetmic.2011.02.014 . hal-00696635

Garcia, B.A., A.T.A. Aguirre-Reyes, K.S. Decena and R.C. Sulabo. 2019. Effect of performance enhancer mixture as replacement for antibiotic growth promoters on production performance, excreta quality and carcass characteristics of broilers. Philipp J Vet Anim Sci 2019 45(1):34-47

Garg, A.K., V. Mudgal, and R.S. Dass. 2008. Effect of organic zinc supplementation on growth, nutrient utilization and mineral profile in lambs. Anim. Feed Sci. Technol. 144, 82-96.

Han, Y.K. and P.A. Thacker. 2010. Effects of antibiotics, zinc oxide or rare earth mineral-yeast on performance, nutrient digestibility and serum parameters in weanling pigs. Asian-Aust. J. Anim. Sci 23 (8); 1057-1065

Hill, G.M., D.C. Mahan, S.D. Carter, G.L.Cromwell, R.C.Ewan, R.L. Harrold, A.J Lewis, P.S. Miller, G.C. Shurson, and T.L. Veum. 2001. Effect of pharmacological concentrations of zinc oxide with or without the inclusion of an antibacterial agent on nursery pig performance. J Anim Sci. 2001 Apr;79(4):934-41. doi: 10.2527/2001.794934x

Hung, Y. T., Q. Hu, R.J. Faris., J. Guo, P.E. Urriola, G.C. Shurson, C. Chen, and M. Saqui-Salces, 2020. Analysis of Gastrointestinal Responses Revealed Both Shared and Specific Targets of Zinc Oxide and Carbadox in Weaned Pigs. Antibiotics (Basel, Switzerland), 9(8), 463. https://doi.org/10.3390/antibiotics9080463

Jahanian, R., H. Moghaddam, Nassiri, and A. Rezaei.. 2008. Improved broiler chick performance by dietary supplementation of organic zinc sources. Asian-Australas. J. Anim. Sci, 21, 1348-1354. doi: 10.5713/ajas.2008.70699

Kidd, M. T., N. B. Anthony, and S. R. Lee. 1992. Progeny performance when dams and chicks are fed supplemental zinc. Poult. Sci. 71:1201-1206.

Kidd, M. T., M. A. Qureshi, P. R. Ferket, and L. M. Thomas. 1994. Blood clearance of Eschericheria coli and evaluation of mononuclear-phagocytic system as influenced by supplemental dietary zinc methionine in young turkeys. Poult. Sci. 73:1318-1389.

Kromm, V. and A. Romeo. 2017. Antibacterial effects of zinc oxide in weaned piglets. International Pig Topics 32 (1); 11-14.

Kumar N.A., V. Kapoor, and V.K. Paliwal.2002. Effect of zinc supplementation in conventional diets on nutrient digestibility, growth and nitrogen balance in kids. Annals of Biological Research 7, 201-206.

Li, B. T., A.G. Van Kessel, W. R. Caine, S.X. Huang, and R. N. Kirkwood. 2001. Small intestinal morphology and bacterial populations in ileal digesta and feces of newly weaned pigs receiving high dietary levels of zinc oxide. Canadian Journal of Animal Science 81: 511516.

Mandal GP, R.S. Dass, D.P. Isore, A.K. Garg, and G.C. Ram. 2007. Effect of zinc supplementation from two sources on growth, nutrient utilization and immune response in male crossbred cattle (Bos indicus . Bos taurus) bulls. Animal Feed Science and Technology 138, 1-12. doi:10.1016/j.anifeedsci.2006.09.014

Miller, E. R., R. W. Leucke, D. E. Ullrey, B. U. Baltzer, B. L. Bradley, and J. A. Holfer. 1968. Biochemical, skeletal and allometric changes due to zinc deficiency in the baby pig. J. Nutr. 95:278-286.

Modi, C.M., S.K. Mody, H.B. Patel, G.B. Dudhatra, A. Kumar and T.J. Sheikh. 2011. Growth promoting use of antimicrobial agents in animals. Journal of Applied Pharmaceutical Science 01 (08); 2011: 33-36 
Morales, J., G. Cordero, C Piñeiro, and S. Durosoy. 2012. Zinc oxide at low supplementation improves productive performance and health status of piglets. J. Anim. Sci. 90: 436-438. doi: $10.2527 / \mathrm{jas} 53833$

Oh,H.-J., Y.-J. Park, J.H Cho, M.-H. Song, B.-H. Gu, W. Yun, J.-H. Lee, J.-S. An, Y.-J Kim. J.-S. Lee. S. Kim, H. Kim, E.-S. Kim, B.-K. Lee, B.-W. Kim, H.-B. Kim, J.-H. Cho, and M.-H. Kim. 2021. Changes in diarrhea score, nutrient digestibility, zinc utilization, intestinal immune profiles, and fecal microbiome in weaned piglets by different forms of zinc. Animals 2021, 11, 1356. https://doi.org/10.3390/ ani11051356

Pimentel, J. L., M. E. Cook, and J. L. Greger. 1991. Immune response of chicks fed various levels of zinc. Poult. Sci. 70:947-954.

Ramiah, S.K., E. A. Awad, S. Mookiah, and Z. Idrus. 2019. Effects of zinc oxide nanoparticles on growth performance and concentrations of malondialdehyde, zinc in tissues, and corticosterone in broiler chickens under heat stress conditions. Poultry Science 98:3828-3838. http://dx.doi.org/10.3382/ps/pez093

Raquipo, J.M.B.R., F.C.C. Reyes, B. A. Moog, E. P. Angeles, A.F.S. Regaspi, and A. M. Cuizon. 2017. Performance of nursery pigs fed diets with coated or potentiated zinc oxide. Philipp $J$ Vet Anim Sci 201743 (2): 133-138

Romeo, A. 2014. Understanding the zinc pathways in animals. All About Feed 22 (7):16-17

Salama, A.A., G. Caja, E. Albanell, X. Such, R. Casals, and J. Plaixats. 2003. Effects of dietary supplements of zinc-methionine on milk production, udder health and zinc metabolism in dairy goats. $J$ Dairy Res. 70(1):9-17. doi: 10.1017/s0022029902005708.

Swinkels, J. W., E. T. Kornegay, and M. W. Verstegen. 1994. Biology of zinc and biological value of dietary organic zinc complexes and chelates. Nutr. Res. Rev. 7:129-149.

Tomaszewska, E, S. Muszyński, P. Dobrowolski, M. Kwiecień, A. Winiarska-Mieczan, I. Świetlicka, and A. Wawrzyniak. 2017. Effect of zinc level and source (Zinc oxide vs. Zinc glycine) on bone mechanical and geometric parameters, and histomorphology in male Ross 308 broiler chicken. Brazilian Journal of Poultry Science 19(1), 159-170. https://doi.org/10.1590/18069061-2016-0285

Vela, G., P Stark, M. Socha, A.K. Sauer, S. Hagmeyer, and A.M. Grabrucker. 2015. Zinc in gut-brain interaction in autism and neurological disorders. Neural plasticity, 972791. https://doi.org/10.1155/2015/972791

Wang, X., M.C. Valenzano, J.M. Mercado, E.P. Zurbach and J.M Mullin. 2013. Zinc supplementation modifies tight junctions and alters barrier function of CACO-2 human intestinal epithelial layers. Dig Dis Sci 58:77-87. doi 10.1007/s10620-012-2328-8.

Weng X, A.P.A Monteiro, J. Guo, C. Li, R.M. Orellana, T.N. Marins, J.K. Bernard, D.J. Tomlinson, J.M. DeFrain, S.E. Wohlgemuth, and S. Tao. 2018. Effects of heat stress and dietary zinc source on performance and mammary epithelial integrity of lactating dairy cows. J Dairy Sci. 101(3):2617-2630. doi: 10.3168/jds.2017-13484.

Zhang B, and Y. Guo. 2009. Supplemental zinc reduced intestinal permeability by enhancing occludin and zonula occludens protein-1 (ZO-1) expression in weaning piglets. Br J Nutr. 2009;102: 687693. doi:10.1017/S0007114509289033. 
345 Table 2. Intestinal morphology of broilers fed with and without potentiated zinc oxide.

\begin{tabular}{|c|c|c|c|c|c|c|c|c|}
\hline \multirow[b]{2}{*}{ Parameters } & \multicolumn{4}{|c|}{ Dietary Treatments } & \multirow[b]{2}{*}{ SEM } & \multicolumn{3}{|c|}{$P$-value } \\
\hline & $\mathrm{NC}$ & PC & $\begin{array}{c}\mathrm{NC}+ \\
\text { pZnO }\end{array}$ & $\begin{array}{c}\mathrm{PC} \\
+\mathrm{pZnO} \\
\end{array}$ & & AGP & pZnO & $\begin{array}{l}\text { AGP* } \\
\text { pZnO }\end{array}$ \\
\hline \multicolumn{9}{|c|}{ Duodenum (day 18) } \\
\hline Villi Height, $\mu \mathrm{m}$ & $1,331.77$ & $1,400.89$ & $1,391.57$ & $1,343.20$ & 74.92 & 0.89 & 0.99 & 0.44 \\
\hline Crypt Depth, $\mu \mathrm{m}$ & 239.43 & 286.32 & 247.13 & 279.06 & 29.40 & 0.11 & 0.99 & 0.76 \\
\hline VH:CD & 5.94 & 5.85 & 6.37 & 5.37 & 0.82 & 0.47 & 0.98 & 0.54 \\
\hline \multicolumn{9}{|l|}{ Jejunum (day 18) } \\
\hline Villi Height, $\mu \mathrm{m}$ & 829.67 & 783.27 & 883.64 & 720.4 & 70.13 & 0.15 & 0.95 & 0.42 \\
\hline Crypt Depth, $\mu \mathrm{m}$ & 196.59 & 185.43 & 211.03 & 167.03 & 18.78 & 0.16 & 0.92 & 0.39 \\
\hline VH:CD & 4.44 & 4.68 & 4.32 & 4.81 & 0.58 & 0.53 & 1.00 & 0.83 \\
\hline \multicolumn{9}{|l|}{ Ileum (day 18) } \\
\hline Villi Height, $\mu \mathrm{m}$ & 592.08 & 602.97 & 606.5 & 580.07 & 49.63 & 0.87 & 0.93 & 0.70 \\
\hline Crypt Depth, $\mu \mathrm{m}$ & 167.93 & 193.43 & 191.20 & 153.22 & 20.93 & 0.76 & 0.68 & 0.13 \\
\hline VH:CD & 3.93 & 3.36 & 3.50 & 4.02 & 0.49 & 0.96 & 0.82 & 0.26 \\
\hline \multicolumn{9}{|c|}{ Duodenum (day 35) } \\
\hline Villi Height, $\mu \mathrm{m}$ & $1165.67^{b}$ & $1442.26^{\mathrm{a}}$ & $1429.63^{a}$ & $1207.37^{\mathrm{ab}}$ & 62.33 & 0.68 & 0.82 & $<0.01$ \\
\hline Crypt Depth, $\mu \mathrm{m}$ & 312.79 & 310.03 & 255.6 & 286.63 & 25.79 & 0.60 & 0.14 & 0.53 \\
\hline VH:CD & $3.75^{\mathrm{b}}$ & $5.40^{\mathrm{ab}}$ & $6.39^{\mathrm{a}}$ & $4.33^{\mathrm{ab}}$ & 0.67 & 0.77 & 0.26 & 0.01 \\
\hline \multicolumn{9}{|l|}{ Jejunum (day 35) } \\
\hline Villi Height, $\mu \mathrm{m}$ & 651.24 & 755.50 & 809.73 & 748.23 & 59.15 & 0.73 & 0.23 & 0.19 \\
\hline Crypt Depth, $\mu \mathrm{m}$ & 208.24 & 201.43 & 203.60 & 171.50 & 22.93 & 0.43 & 0.48 & 0.60 \\
\hline VH:CD & 3.30 & 4.20 & 4.23 & 4.91 & 0.47 & 0.12 & 0.11 & 0.82 \\
\hline \multicolumn{9}{|l|}{ Ileum (day 35) } \\
\hline Villi Height, $\mu \mathrm{m}$ & 485.41 & 545.53 & 618.23 & 486.04 & 53.42 & 0.49 & 0.49 & 0.07 \\
\hline Crypt Depth, $\mu \mathrm{m}$ & $172.56^{\mathrm{ab}}$ & $184.63^{\mathrm{ab}}$ & $195.80^{\mathrm{a}}$ & $134.30^{\mathrm{b}}$ & 17.58 & 0.16 & 0.43 & 0.04 \\
\hline VH:CD & 2.91 & 3.09 & 3.33 & 3.76 & 0.34 & 0.36 & 0.11 & 0.71 \\
\hline
\end{tabular}


356 Table 3. Nutrient digestibility of experimental broiler diets.

\begin{tabular}{|c|c|c|c|c|c|c|c|c|}
\hline & \multicolumn{4}{|c|}{ Dietary Treatments } & \multirow[b]{2}{*}{ SEM } & \multicolumn{3}{|c|}{$P$-value } \\
\hline & $\mathbf{N C}$ & $\mathbf{P C}$ & $\begin{array}{l}\mathrm{NC}+ \\
\text { pZnO }\end{array}$ & $\begin{array}{c}\mathrm{PC}+ \\
\text { pZnO }\end{array}$ & & AGP & pZnO & $\begin{array}{l}\text { AGP* } \\
\text { pZnO }\end{array}$ \\
\hline $\mathrm{GE}, \mathrm{kcal} / \mathrm{kg}$ & 4,022 & 4,047 & 4,022 & 4,031 & & & & \\
\hline $\mathrm{AME}, \mathrm{kcal} / \mathrm{kg}$ & $3,366^{\mathrm{a}}$ & $3,159^{b}$ & $3,187^{\mathrm{b}}$ & $3,390^{\mathrm{a}}$ & 28.86 & 0.94 & 0.37 & $<.0001$ \\
\hline $\mathrm{COD}_{\mathrm{GE}}, \%$ & $75.49^{\mathrm{a}}$ & $70.62^{\mathrm{b}}$ & $71.82^{\mathrm{b}}$ & $76.11^{\mathrm{a}}$ & 0.65 & 0.66 & 0.17 & $<.0001$ \\
\hline Dry Matter & $69.63^{\mathrm{a}}$ & $64.28^{\mathrm{b}}$ & $64.77^{\mathrm{b}}$ & $71.22^{\mathrm{a}}$ & 0.77 & 0.48 & 0.19 & $<.0001$ \\
\hline Crude Protein & $54.85^{\mathrm{a}}$ & $48.12^{\mathrm{b}}$ & $47.63^{\mathrm{b}}$ & $59.89^{\mathrm{a}}$ & 1.61 & 0.08 & 0.14 & $<.0001$ \\
\hline Ether extract & $88.62^{\mathrm{ab}}$ & $85.77^{\mathrm{b}}$ & $86.5^{\mathrm{ab}}$ & $91.06^{\mathrm{a}}$ & 1.49 & 0.496 & 0.21 & 0.01 \\
\hline
\end{tabular}

Table 4. Performance of broilers fed diets with and without potentiated zinc oxide combinations

\begin{tabular}{|c|c|c|c|c|c|c|c|c|}
\hline & \multicolumn{4}{|c|}{ Dietary Treatments } & \multirow[b]{2}{*}{ SEM } & \multicolumn{3}{|c|}{$P$-value } \\
\hline & $\mathrm{NC}$ & PC & $\begin{array}{l}\mathrm{NC}+ \\
\mathrm{pZnO}\end{array}$ & $\begin{array}{l}\mathrm{PC}+ \\
\text { pZnO }\end{array}$ & & AGP & pZnO & $\begin{array}{l}\text { AGF } \\
\text { pZn }\end{array}$ \\
\hline \multicolumn{9}{|c|}{ Body weight, $g$} \\
\hline $\mathrm{d} 0$ & 47.70 & 48.00 & 47.90 & 47.70 & 0.37 & & & \\
\hline d 7 & 168.00 & 169.00 & 172.00 & 168.00 & 4.34 & 0.76 & 0.67 & 0 . \\
\hline d 14 & 408.00 & 418.00 & 425.00 & 417.00 & 8.08 & 0.88 & 0.32 & 0 . \\
\hline $\mathrm{d} 21$ & 970.00 & 986.00 & 999.00 & 980.00 & 20.36 & 0.97 & 0.57 & 0. \\
\hline d 28 & $1,390.00$ & $1,432.00$ & $1,443.00$ & $1,398.00$ & 22.59 & 0.62 & 0.36 & 0 . \\
\hline d 35 & $2,038.00$ & $2,052.00$ & $2,090.00$ & $2,048.00$ & 28.41 & 0.63 & 0.38 & 0.3 \\
\hline
\end{tabular}

Body weight gain, $g$

$\begin{array}{lllllllll}0-7 \mathrm{~d} & 119.96 & 121.24 & 124.36 & 120.42 & 4.43 & 0.75 & 0.66 & 0.53 \\ 8-14 \mathrm{~d} & 240.44 & 249.01 & 252.83 & 249.33 & 6.73 & 0.71 & 0.35 & 0.38 \\ 15-21 \mathrm{~d} & 561.50 & 567.94 & 573.63 & 562.94 & 14.25 & 0.87 & 0.79 & 0.52 \\ 22-28 \mathrm{~d} & 420.86 & 446.29 & 444.27 & 444.82 & 18.28 & 0.48 & 0.55 & 0.50 \\ 29-35 \mathrm{~d} & 646.92 & 619.77 & 646.65 & 623.16 & 21.18 & 0.22 & 0.94 & 0.93\end{array}$

Feed intake, g

$\begin{array}{lcccccccc}0-7 \mathrm{~d} & 131.22 & 140.95 & 132.34 & 118.24 & 7.42 & 0.78 & 0.17 & 0.13 \\ 8-14 \mathrm{~d} & 392.01^{\mathrm{a}} & 381.36^{\mathrm{ab}} & 379.33^{\mathrm{ab}} & 352.30^{\mathrm{b}} & 7.57 & 0.02 & 0.01 & 0.29 \\ 15-21 \mathrm{~d} & 686.12 & 678.71 & 674.87 & 674.22 & 11.59 & 0.74 & 0.51 & 0.78 \\ 22-28 \mathrm{~d} & 913.42 & 919.42 & 952.8 & 927.69 & 15.15 & 0.53 & 0.13 & 0.31 \\ 29-35 \mathrm{~d} & 1,053.06 & 1,034.59 & 1,091.95 & 1,062.77 & 34.36 & 0.49 & 0.34 & 0.88\end{array}$

FCR

\begin{tabular}{|c|c|c|c|c|c|c|c|c|}
\hline $0-7 \mathrm{~d}$ & 1.08 & 1.17 & 1.06 & 1.01 & 0.59 & 0.81 & 0.09 & 0.19 \\
\hline $8-14 d$ & $1.65^{\mathrm{a}}$ & $1.54^{\mathrm{ab}}$ & $1.51^{\mathrm{ab}}$ & $1.41^{\mathrm{b}}$ & 0.50 & 0.05 & 0.01 & 0.90 \\
\hline $15-21 \mathrm{~d}$ & 1.24 & 1.20 & 1.18 & 1.20 & 0.03 & 0.72 & 0.37 & 0.33 \\
\hline $22-28 d$ & 2.18 & 2.08 & 2.17 & 2.16 & 0.09 & 0.59 & 0.68 & 0.61 \\
\hline $29-35 d$ & 1.63 & 1.68 & 1.70 & 1.77 & 0.85 & 0.50 & 0.36 & 0.91 \\
\hline
\end{tabular}


367 Table 5. Fecal scores of broilers fed with and without potentiated zinc oxide.

\begin{tabular}{|c|c|c|c|c|c|c|c|c|}
\hline & \multicolumn{4}{|c|}{ Dietary Treatments } & \multirow[b]{2}{*}{ SEM } & \multicolumn{3}{|c|}{$P$-value } \\
\hline & NC & PC & $\begin{array}{l}\mathrm{NC}+ \\
\text { pZnO }\end{array}$ & $\begin{array}{c}\mathrm{PC}+ \\
\text { pZnO }\end{array}$ & & AGP & pZnO & $\begin{array}{l}\text { AGP: } \\
\text { pZnO }\end{array}$ \\
\hline d $0-7$ & $2.16^{\mathrm{a}}$ & $2.13^{\mathrm{a}}$ & $2.02^{\mathrm{b}}$ & $1.96^{\mathrm{b}}$ & 0.09 & 0.54 & 0.04 & 0.84 \\
\hline d $8-14$ & 2.06 & 1.97 & 1.98 & 1.86 & 0.10 & 0.30 & 0.38 & 0.89 \\
\hline d 15-21 & 2.12 & 2.00 & 2.04 & 1.98 & 0.10 & 0.34 & 0.62 & 0.76 \\
\hline d 22-28 & 2.08 & 2.03 & 1.91 & 1.90 & 0.08 & 0.74 & 0.08 & 0.80 \\
\hline d 29-35 & 1.98 & 1.90 & 1.94 & 1.83 & 0.07 & 0.13 & 0.38 & 0.79 \\
\hline
\end{tabular}

$1{ }^{\text {ab }}$ Means within a row with different superscripts are significantly different $(P<0.05)$

2 Dietary treatments were Negative Control (NC); Positive Control (PC; NC $+500 \mathrm{~g} /$ ton Maduramicin ammonium $10 \mathrm{~g}+500$ $\mathrm{g} /$ ton Zinc bacitracin 150); NC added with $150 \mathrm{~g} /$ ton potentiated $(\mathrm{NC}+\mathrm{pZnO})$; and $\mathrm{PC}$ added with $150 \mathrm{~g} /$ ton potentiated zinc oxide $(\mathrm{PC}+\mathrm{pZnO})$ 